\title{
Thirty Neurological Eponyms Associated with the Nazi Era
}

\author{
Daniel Kondziella
}

Department of Neurology, Sahlgrenska University Hospital, Gothenburg, Sweden

\section{Key Words}

Asperger syndrome $\cdot$ Creutzfeldt-Jakob disease $\cdot$

Euthanasia - Gerstmann-Sträussler-Scheinker disease • Hallervorden-Spatz syndrome $\cdot$ Lewy body dementia . Niemann-Pick disease $\cdot$ Rett syndrome $\cdot$ Seitelberger disease $\cdot$ Wallenberg's syndrome

\begin{abstract}
In the 1920s, the neurosciences in Germany were worldclass. Then came Hitler's regime, and with it 2 distinct changes happened to the research milieus in Berlin and elsewhere. First, the persecution of Jews and others deprived Germany of many of its most outstanding scientists. Second, numerous German and Austrian physicians became active in $\mathrm{Na}$ tional Socialist (NS)-euthanasia programs. In recent years, the medical community has become more aware of the ethical burden associated with eponyms derived from scientists of the Third Reich. Yet a list of these eponyms with emphasis on clinical neurology is still missing. This paper therefore reviews 30 neurological eponyms derived from 29 physicians who lived in the Nazi era. Among them are victims who were forced out of the country or murdered in concentration camps, protestors who risked their academic careers and often their lives, beneficiaries who published on brains from 'euthanized' children, and collaborators who were directly involved in the planning and execution of NS-euthanasia programs.

Copyright $\odot 2009$ S. Karger AG, Basel
\end{abstract}

\section{Introduction}

The 1920s were a period of exceptional advancement for the neurosciences in Germany [1]. Then came the Nazi era and the research milieus in Berlin and elsewhere changed profoundly. The persecution of Jews and others deprived Germany of numerous world-leading scientists. Ludwig Pick and Arthur Simons lost their lives in concentration camps and countless others had to emigrate, including Friedrich Heinrich Lewy, Franz Kallmann and Max Bielschowsky. 'Aryan' physicians were able to take attractive vacant posts and, as has been pointed out by Shevell [2], a symbiotic relationship developed between these physicians and Hitler's regime. The Nazis pursued the systematic extinction of 'lives not worth living' [3], and the medical community provided the scientific basis for 'racial hygiene', thereby enhancing its own prestige and power [2]. Scientists such as Julius Hallervorden and Hugo Spatz became active in National Socialist (NS)-euthanasia programs and collected the brains of 'euthanized' children and adults. They, together with others such as Franz Seitelberger, profited scientifically from this material after the Second World War. Only a few scientists protested against the Nazi regime, these included Jules Tinel and Oscar and Cécile Vogt. Numerous others, however, were more ambivalent, and prominent examples are Hans Gerhard Creutzfeldt and Andreas Rett.

\section{KARGER}

Fax +4161306 1234

E-Mail karger@karger.ch

www.karger.com
(C) 2009 S. Karger AG, Basel

0014-3022/09/0621-0056\$26.00/0

Accessible online at:

www.karger.com/ene
Daniel Kondziella

Department of Neurology, Sahlgrenska University Hospital

SE-41345 Gothenburg (Sweden)

Tel. +46730791 599, Fax +4631826227

E-Mail daniel_kondziella@yahoo.com 
Table 1. Neurological eponyms derived from names of perpetrators

\begin{tabular}{|c|c|c|}
\hline & Actions & Eponym \\
\hline $\begin{array}{l}\text { Collaborators } \\
\text { Julius Hallervorden (1882-1965). } \\
\text { Neuropathologist. Berlin and Giessen } \\
\text { (Germany) }[6,36]^{1} \text {. }\end{array}$ & See text. & $\begin{array}{l}\text { Hallervorden-Spatz disease: pantothenate } \\
\text { kinase-associated neurodegeneration with } \\
\text { brain iron accumulation. }\end{array}$ \\
\hline $\begin{array}{l}\text { Hans Joachim Scherer (1906-1945). } \\
\text { Neuropathologist. Berlin, Antwerp and } \\
\text { Breslau (today Wrocław, Poland). } \\
\text { Died in Allied air raid [37]. }\end{array}$ & $\begin{array}{l}\text { Examined the brains of more than } \\
300 \text { NS-euthanasia victims during the } \\
\text { Second World War. }\end{array}$ & $\begin{array}{l}\text { Van Bogaert-Scherer-Epstein syndrome } \\
\text { (cerebrotendinous xanthomatosis): lipid } \\
\text { storage disease with tendon xanthomas, } \\
\text { cataracts, dementia and ataxia. }\end{array}$ \\
\hline $\begin{array}{l}\text { Hugo Spatz }(1888-1969) \text {. } \\
\text { Neuropathologist. Berlin and Giessen } \\
\text { (Germany) }[4,6]^{1} \text {. }\end{array}$ & $\begin{array}{l}\text { Collected the brains of several hundred } \\
\text { NS-euthanasia victims and scientifically } \\
\text { exploited these specimens in collabora- } \\
\text { tion with Julius Hallervorden. }\end{array}$ & Hallervorden-Spatz disease. See above. \\
\hline $\begin{array}{l}\text { Beneficiary } \\
\text { Franz Seitelberger (1916-2007). } \\
\text { Neurologist and neuropathologist. } \\
\text { Vienna }[12,15]^{1} \text {. }\end{array}$ & See text. & $\begin{array}{l}\text { Seitelberger disease: infantile neuroaxonal } \\
\text { dystrophy. Sudanophilic leukodystrophy of } \\
\text { the Seitelberger type: variant of Pelizaeus- } \\
\text { Merzbacher disease. }\end{array}$ \\
\hline
\end{tabular}

Places indicate site of main professional engagement. ${ }^{1}$ Only selected references are shown, see text for further details.

There is increasing recognition of the ethical burden associated with eponyms from scientists of the Nazi era [4], yet a list of such eponyms with emphasis on clinical neurology is still lacking. This paper therefore lists $30 \mathrm{ep}-$ onyms and their describers, classified according to Raul Hilberg into perpetrators (table 1), victims (table 2) and bystanders (table 3) [5]. Perpetrators are further divided into collaborators, who were directly involved in NSeuthanasia programs, and beneficiaries, who advanced their academic profile in the post-war period by publishing on material derived from 'euthanized' victims. Bystanders are grouped into protestors and physicians who played ambivalent roles during the Nazi era. To elucidate the diversity of fates and actions associated with the eponyms in this paper, the most representative biographies from each category are provided below in greater detail.

\section{Perpetrators}

\section{Collaborators}

Julius Hallervorden (fig. 1) is the best-known physician to be honored with a neurological eponym despite his involvement in NS-euthanasia. At the beginning of the Second World War, Hallervorden was a professor of neuropathology at the Kaiser Wilhelm Brain Research

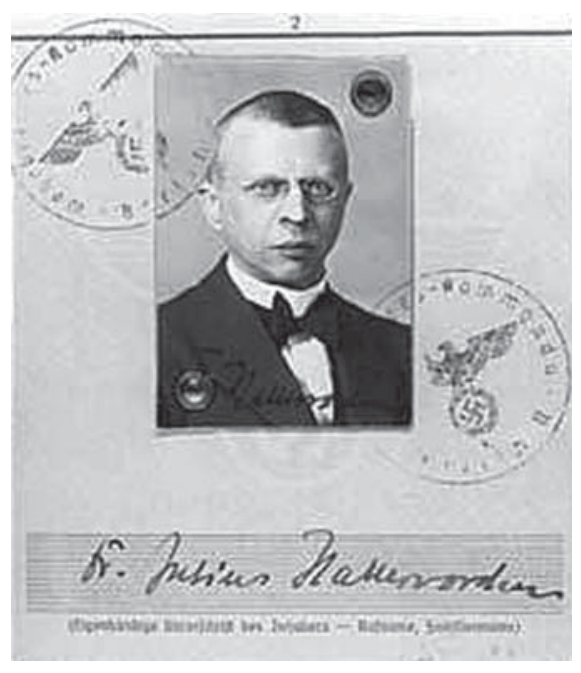

Fig. 1. Julius Hallervorden (1882-1965), ca. 1935.

Institute in Berlin and the Brandenburg State Hospital. The latter was 1 of 6 elimination centers established under the Nazi 'euthanasia' program code-named T4. Over 70,000 patients with various brain diseases were killed by barbiturate injections or gassing with carbon monoxide in disguised shower facilities. Hallervorden personally 
Table 2. Neurological eponyms derived from names of victims

\begin{tabular}{lll}
\hline & Fate & Eponym \\
\hline $\begin{array}{l}\text { Physicians who lost their lives } \\
\begin{array}{l}\text { Lucja Frey-Gottesman (1889-1942?). } \\
\text { Neurologist. Lviv (Poland, now Ukraine) }\end{array}\end{array}$ & $\begin{array}{l}\text { Died in Lviv Ghetto, exact date } \\
\text { unknown. }\end{array}$ & $\begin{array}{l}\text { Frey syndrome: auriculo-temporal nerve neuralgia due to } \\
\text { parotid gland tumor or surgery. }\end{array}$ \\
\hline $\begin{array}{l}\text { Ludwig Pick (1868-1944). } \\
\text { Neuropathologist. Berlin [1,24] } .\end{array}$ & See text. & $\begin{array}{l}\text { Niemann-Pick disease A-C: lysosome storage diseases } \\
\text { with sphingomyelin accumulation. }\end{array}$ \\
\hline $\begin{array}{l}\text { Joannes Cassianus Pompe (1901-1945). } \\
\text { Pathologist. Amsterdam [39]. }\end{array}$ & $\begin{array}{l}\text { Executed by German occupying } \\
\text { forces for participation in Dutch } \\
\text { resistance movement. }\end{array}$ & $\begin{array}{l}\text { Pompe disease: glycogen storage myopathy due to acid } \\
\text { maltase deficiency (glycogenosis type II). }\end{array}$ \\
\hline $\begin{array}{l}\text { Arthur Simons (1879-1942). } \\
\text { Neurologist. Berlin [4, 40]. }\end{array}$ & $\begin{array}{l}\text { Died in Vaivara concentration } \\
\text { camp (Estonia). }\end{array}$ & $\begin{array}{l}\text { Barraquer-Simons syndrome: upper body lipodystrophy } \\
\text { with deafness, epilepsy, mental defects. }\end{array}$ \\
\hline $\begin{array}{l}\text { Wladyslaw Sterling (1877-1943). } \\
\text { Neurologist. Warsaw [41, 42]. }\end{array}$ & Murdered by German Gestapo. & $\begin{array}{l}\text { Sterling reflex: blow of reflex hammer on volar side of } \\
\text { digits II-IV induces finger flexion. }\end{array}$ \\
\hline
\end{tabular}

\section{Physicians forced to emigrate}

Alfred Bielschowsky (1871-1940).

Ophthalmologist. Breslau (today Wrocław,

Emigrated to USA.

Bielschowsky sign: characteristic head posture with trochlear nerve palsy.

Poland) [1].

Max Bielschowsky (1869-1940)

Neuropathologist. Berlin [1, 43].

Emigrated to UK.

Jansky-Bielschowsky disease: late infantile neuronal ceroid lipofuscinosis.

Joseph Gerstmann (1887-1969).

Emigrated to USA.

Neurologist. Vienna $[1,44]$.

Gerstmann-Sträussler-Scheinker disease: a familial prion disease. Gerstmann syndrome: finger agnosia, agraphia, right-left disorientation, dyscalculia.

Franz Josef Kallmann (1897-1965).

Neuropathologist. Berlin [1].

Kallmann syndrome: hypothalamic hypogonadism, anosmia.

Friedreich Heinrich Lewy (1885-1950). Emigrated to USA.

Neurologist. Berlin [1].

Lewy body dementia: fluctuating cognitive symptoms, Parkinsonism, hallucinations.

Ilya Mark Scheinker (1902-1954).

Neurologist. Vienna, Paris $[1,44]$.

Gerstmann-Sträussler-Scheinker disease. See above.

Adolf Wallenberg (1862-1949).

Internist. Gdansk (Poland) [1].

Emigrated to USA.

Wallenberg syndrome: lateral medullary infarction usu-

Emigrated to UK/USA. ally due to posterior inferior cerebellar artery occlusion.

Robert Wartenberg (1886-1956). Emigrated to USA.

Neurologist. Freiburg (Germany) [1].

Wartenberg sensory migrant neuritis: painful, but benign, sensory mononeuritis multiplex. Wartenberg sign: synkinesis ('jaw-winking') after Bell's palsy.

Wartenberg syndrome: distal forearm pain due to entrapment of superficial radial nerve branch.

\section{Physicians forced to leave office}

Adolf Heidenhain (1893-1937).

Neuropathologist. Tübingen (Germany) [1].

Ernst Moro (1874-1951).

Pediatrician. Heidelberg (Germany) [45].

Ernst Sträussler (1872-1959).

Neurologist. Vienna [44, 46].
Denied professorship in

Tübingen for racial reasons.

Forced to leave chair of

Heidelberg Children Hospital

because of marriage to Jewish

wife.
Heidenhain variant: Creutzfeldt-Jacob disease with visual impairment and hallucinations.

Moro reflex: startle reflex of infants, usually seen in the first 3 months of life.

Places indicate site of main professional engagement. ${ }^{1}$ Only selected references are shown, see text for further details. 
Table 3. Neurological eponyms derived from names of bystanders

\begin{tabular}{lll}
\hline & Actions & Eponym \\
\hline $\begin{array}{l}\text { Protestors } \\
\text { Joannes Cassianus Pompe (1901-1945). } \\
\text { Pathologist. Amsterdam [39]. }\end{array}$ & $\begin{array}{l}\text { Executed by German occupying forces } \\
\text { for participation in Dutch resistance } \\
\text { movement. }\end{array}$ & $\begin{array}{l}\text { Pompe disease: glycogen storage myopathy } \\
\text { due to acid maltase deficiency (glycogeno- } \\
\text { sis type II). }\end{array}$ \\
\hline $\begin{array}{l}\text { Walther Spielmeyer (1879-1935). } \\
\text { Neurologist. Munich [47, 48]. }\end{array}$ & $\begin{array}{l}\text { Protested against the dismissal of Jewish } \\
\text { colleagues and openly denounced Nazi } \\
\text { regime. }\end{array}$ & $\begin{array}{l}\text { Batten-Spielmeyer-Vogt disease: juvenile } \\
\text { neuronal ceroid lipofuscinosis. }\end{array}$ \\
\hline $\begin{array}{l}\text { Jules Tinel (1879-1952). } \\
\text { Neurologist. Paris [49]. }\end{array}$ & $\begin{array}{l}\text { Participated in French resistance move- } \\
\text { ment and helped organize transport of } \\
\text { wounded Allied pilots to Spain. Son mur- } \\
\text { dered in Neuhausen concentration camp. }\end{array}$ & $\begin{array}{l}\text { Tinel sign: paresthesias in distal extremity } \\
\text { with percussion of injured nerve. }\end{array}$ \\
\hline $\begin{array}{l}\text { Cécilie Vogt (1870-1962). } \\
\text { Neuropathologist. Berlin [26] }\end{array}$ & See text. & \\
\hline $\begin{array}{l}\text { Oskar Vogt (1870-1959). } \\
\text { Neuropathologist. Berlin [26] }\end{array}$ & See text. & $\begin{array}{l}\text { Vogt-Vogt syndrome: extrapyramidal } \\
\text { disorder in early childhood with bilateral } \\
\text { athetosis. }\end{array}$ \\
\hline
\end{tabular}

Physicians with ambivalent roles

Hans Asperger (1906-1980).

Pediatrician. Vienna [50].
Served in German army in Croatia during World War II. Has been accused on uncertain grounds of harboring sympathy for Nazi politics. Cautiously defended mentally disabled children.

Karl Bonhoeffer (1868-1948). Neurologist, psychiatrist. Berlin [51].
Recommended forced sterilization as court consultant, but openly detested Hitler regime. Tried to prevent dismissal of Jewish assistant physicians. Two sons executed for participation in resistance movement.
Asperger syndrome: autism spectrum disorder.

Bonhoeffer reaction: general term for acute organic psychosis.
Hans Gerhard Creutzfeldt (1885-1964). See text.

Neurologist. Kiel (Germany) [27-29] ${ }^{1}$.
Creutzfeldt-Jakob disease: the most common prion disease. SiemerlingCreutzfeldt disease: another term for adrenoleukodystrophy.

Nonne-Marie syndrome: similar to Friedreich ataxia.

Neurologist. Hamburg [52, 53].

Andreas Rett (1924-1997).

Pediatrician. Vienna [31-33] $]^{1}$.
Advocated 'euthanasia', but supported Jewish colleagues.

See text.
Rett syndrome: developmental disorder in girls with characteristic hand-wringing movements, ataxia, epilepsy, dementia.

Places indicate site of main professional engagement. ${ }^{1}$ Only selected references are shown, see text for further details.

selected and examined living patients before removing their brains on site [6]. During these years, he and his friend Hugo Spatz collected several hundred brains derived from the T4 program [6]. Hallervorden called their work an 'exemplary collaboration' [7], and Spatz said it was 'as intense as it was harmonic and would only be disturbed by the approaching war' [8]. Based on the mate- rial from 'euthanized' patients, Hallervorden published 12 papers after the war, several of which are listed in Medline. Hallervorden later admitted his involvement in the T4 operation and its scientific exploitation in the oftenquoted conversation with Leo Alexander, a Jewish neurologist and Holocaust refugee. Hallervorden said, 'I told them, "Look here now, boys. If you are going to kill all 
Fig. 2. Franz Seitelberger (1916-2007) in 1975.

Fig. 3. Ludwig Pick (1868-1944), date unknown.
2

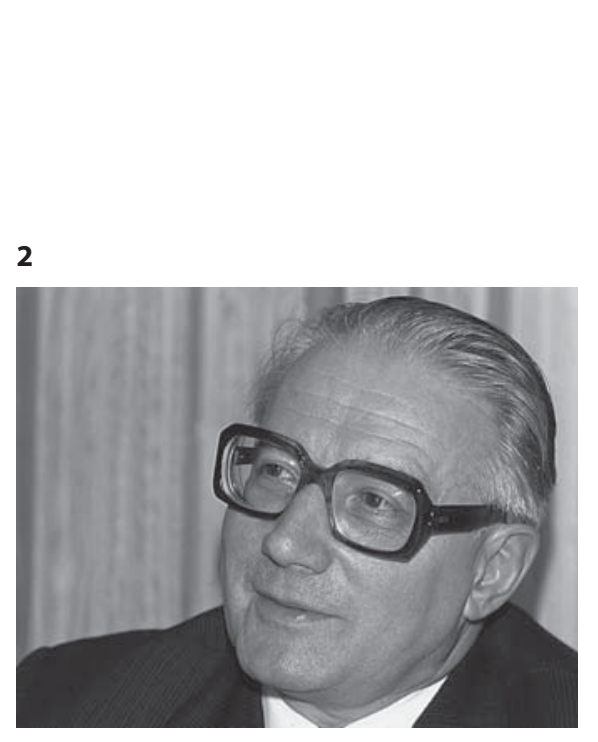

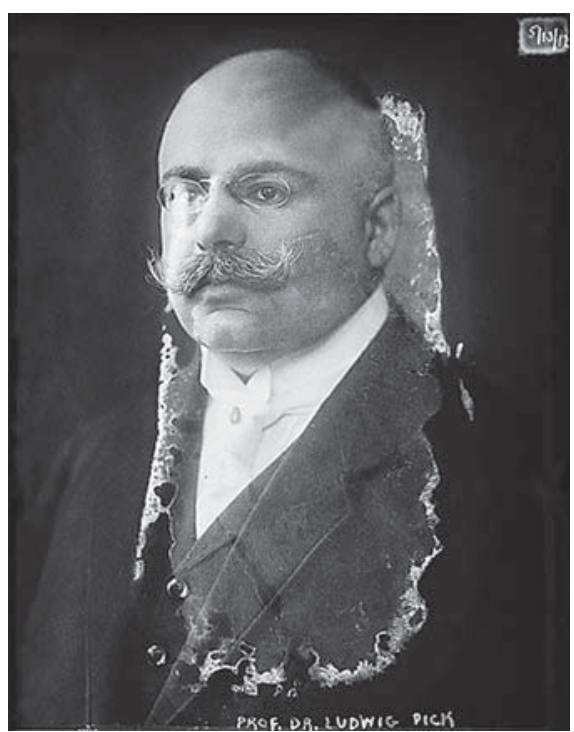

those people, at least take the brains out so that the material can be utilized." They asked me, "How many can you examine?" and so I told them ... the more the better.' Although he felt at times 'slightly nauseated', Hallervorden 'accepted the brains, of course. Where they came from and how they came to me was really none of my business' [9]. After the Second World War Hallervorden became President of the German Neuropathological Society and continued his research undisturbed at the Max Planck Institute in Giessen, Germany.

\section{Beneficiaries}

Franz Seitelberger (fig. 2), a Vienna neurologist and former member of the SS [10,11], may serve as an example of physicians who, although never involved in the planning or execution of NS-euthanasia, benefited from it scientifically during the post-war period. Examining the brains of 3 'euthanasia' victims from the Landesanstalt Görden in Brandenburg, Seitelberger earned his PhD in 1954 under the supervision of Julius Hallervorden [11]. The disorder described in this work is known as sudanophilic leukodystrophy of the Seitelberger type [12]. In his paper Seitelberger acknowledges Hans Heinze for the provision of the medical history and the anatomic specimen [12]. Heinze had been director of the mental health institution in Görden, where he supervised the murder of hundreds of children whose brains he then supplied to neuropathologists and other scientists [11]. Afterwards, Seitelberger worked together with the NS-euthanasia physician Heinrich Gross (1915-2005) who had been di- rectly involved in the systematic murder of cognitively disabled children at the Spiegelgrund hospital in Vienna [13-15]. Like Hallervorden and Spatz, Gross had gathered a large collection of specimens from 'euthanized' children, which served as the basis for his academic work after the war [10, 13-15]. Between 1955 and 1966, Seitelberger and Gross published 5 papers together that can be found in Medline [16-20]. At least 2 papers that Seitelberger has co-authored were based on the brains of 'euthanized' children from Spiegelgrund hospital $[10,14,15$, 21]. Gross and Seitelberger continued to publish together in the 1980s after it had become apparent that Gross was a war criminal [22]. Seitelberger remained to his death a highly honored scientist. He was rector of Vienna University in the 1970s, chair of various international societies and received an impressive number of scientific awards [23].

\section{Victims}

Ludwig Pick (fig. 3) studied medicine in Heidelberg, Leipzig, Berlin and Königsberg. He obtained his doctorate in Leipzig in 1893 and became a professor of pathology at Friedrichshain Hospital in Berlin in 1909 [1, 4, 24]. He was known worldwide and gave invited lectures in New York in 1913 and 1914. Thereafter, Pick served with distinction in the German army during the First World War. Pick's research included many areas of pathology. In addition to Nieman-Pick disease, he has been honored 
Fig. 4. Cécilie Vogt (1870-1962), second from left, and Oskar Vogt (1870-1959), fourth from left, in their laboratory in Berlin, in 1902 or 1903 . To the very left is Korbinian Brodmann (1868-1918), whose name is given to the Brodmann classification for cytoarchitectonic categorization of the cerebral cortex.

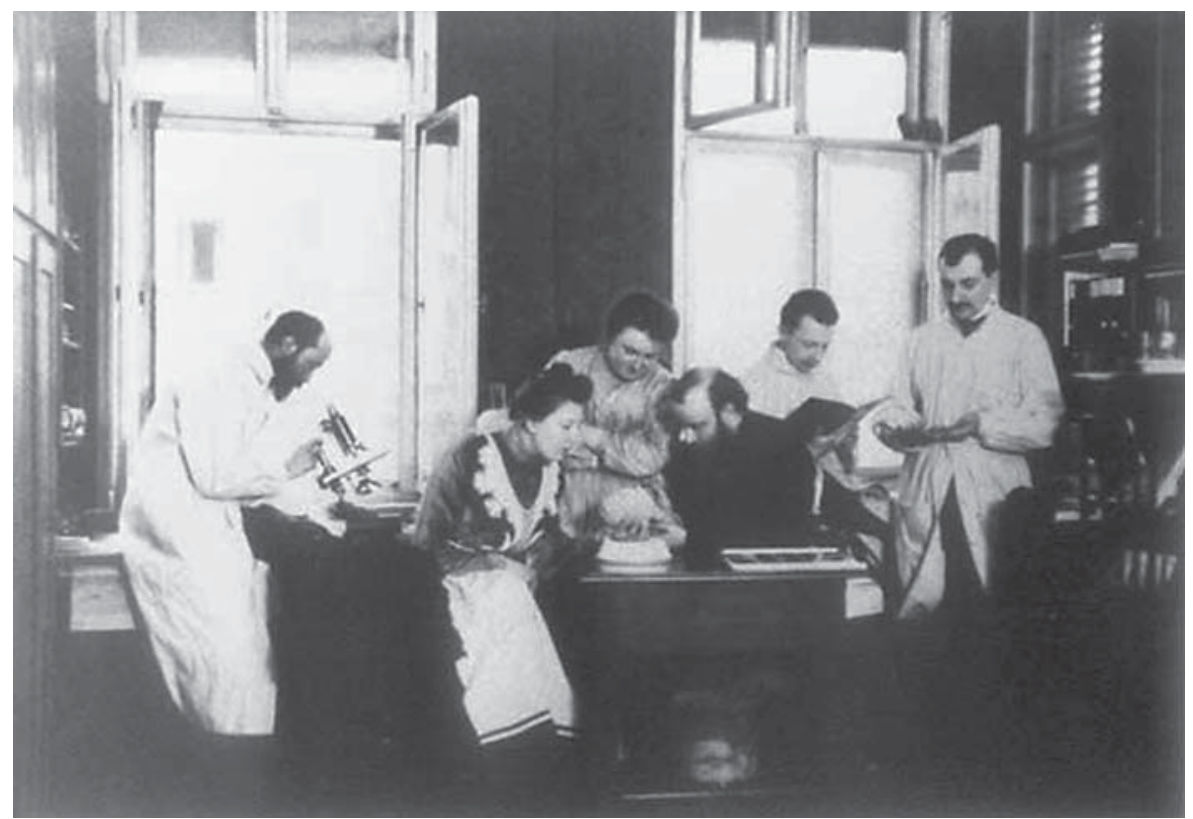

with several eponyms unrelated to neurosciences [4]. He was Dunham Lecturer at Harvard Medical School in 1931-1932 [1, 24].

In 1933, 2 months after Hitler had come to power, the Nazi regime passed the 'Law for the Restoration of the Professional Civil Service' which was intended to remove Jewish and other civil servants of 'non-Aryan' descent from their posts. Shortly after, a similar law was passed that targeted other professional groups such as doctors and lawyers. Thus, Pick was discharged from his post in Berlin in 1933 [1, 24]. His successor was Franz Büchner (1895-1991) who later became one of the few prominent German physicians who spoke out against NS-euthanasia [1]. Refusing to emigrate, Pick stayed in Berlin until he was arrested in 1943. He died on February 3, 1944, in the Theresienstadt concentration camp $[1,24]$. The quote 'Love is a psychosis that always may be given a good prognosis' has been attributed to Pick, a convinced bachelor [24]. He should not be confused with Arnold Pick (18511924), who gave his name to Pick dementia.

\section{Bystanders}

\section{Protesters}

Oskar Vogt and Cécile Vogt (born Mugnier; fig. 4) were spouses and colleagues. They met in Paris at the Salpetrière Hospital and married in 1899. The couple estab- lished the Kaiser Wilhelm Brain Research Institute in Berlin that soon became one of the most prestigious neuroscience centers in the world. In 1924, Oskar Vogt followed an invitation from the Soviet government to examine Lenin's brain [25]. For several years the Vogt couple headed simultaneously the Institute in Berlin and the Moscow Brain Research Institute. They openly detested Hitler's regime and its ideology of 'racial hygiene'. Oskar Vogt considered science as entirely cosmopolitan and did not bow to the pressure to select his personnel according to racial rather than academic considerations [26]. Consequently, the Nazis resorted to open terror. During 2 nighttime raids in 1933, the Vogts were threatened with pistols, their employees physically tortured and laboratory equipment destroyed [26]. Being a very illustrious couple with contacts to the Krupp and Rockefeller families, Oskar and Cécile Vogt managed to survive when the Nazis forced them out of office in 1937. Hugo Spatz succeeded Oskar Vogt as director of the Kaiser Wilhelm Institute. Spatz reconciled its research profile with the regime's racial ideology by focusing on hereditary diseases that the Nazis planned to eliminate [26]. This resulted in Spatz's collaboration with Julius Hallervorden and NSeuthanasia. Turning down attractive offers from the USA, Switzerland and Sweden, Oskar and Cécile Vogt founded a new research institute in Neustadt (Black Forest, Germany) with financial help of the Krupp and the Rockefeller foundations [26]. During the Second World War the 
6

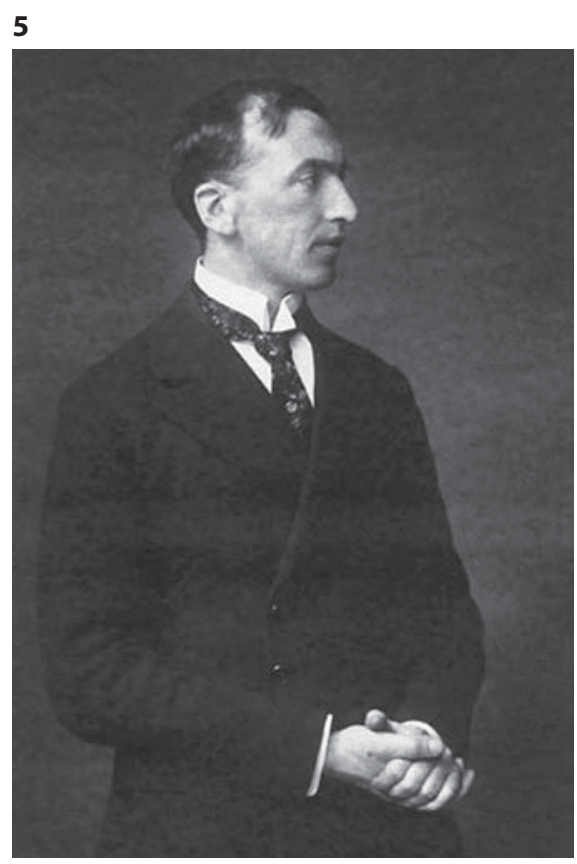

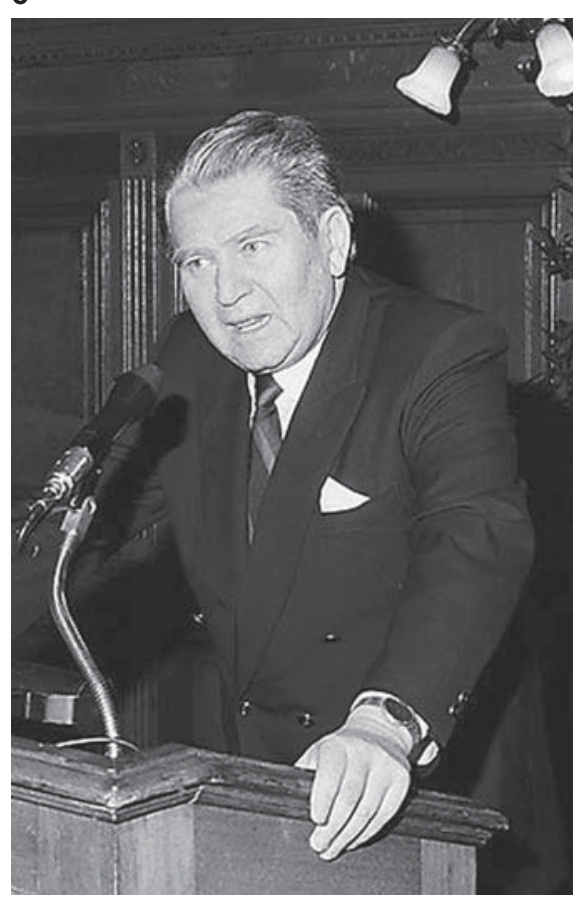

Fig. 5. Hans Gerhard Creutzfeldt (18851964), ca. 1920.

Fig. 6. Andreas Rett (1924-1997) in 1987.

Vogts hid several Jewish refugees, among them the former editor-in-chief of one of Germany's most respectable newspapers, Die Frankfurter Zeitung [26]. After the war, in an ironic twist, Oskar Vogt sent a letter to the International Military Tribunal for the Nuremburg Trials stating his interest in examining the brains of major Nazi criminals in cases where they would be condemned to death. This proposal, however, was 'too hot to handle' and turned down [26]. Oskar and Cécile Vogt should not be confused with Alfred Vogt (1879-1943) of Vogt-Koyanagi-Harada syndrome, or Heinrich Vogt (1875-1936) of Batten-Spielmeyer-Vogt disease.

\section{Physicians with Ambivalent Roles}

Hans Gerhard Creutzfeldt (fig. 5) was a German neurologist and neuropathologist whose scientific contribution to the description of Creutzfeldt-Jakob disease has been disputed $[27,28]$. Although Creutzfeldt had made clear that he disliked Nazi policies, he became an associate member of the SS in 1932 [29]. During the Second World War he was director of the Clinic for Psychiatry and Neurology in Kiel, Germany, from which over 600 patients were transported to provincial hospitals in Schleswig-Holstein where many of them - predictably lost their lives as part of the T4 operation. Creutzfeldt prevented the transportation of patients [4], however, much less frequently than previously thought [29]. In their 2005 review of Creutzfeldt's life and work, Wolf and Foley [29] said that his statement that he was 'a decided opponent of the murder of the psychiatrically ill' was not consistent with his lack of energy in the prevention of such murders. In 1941 and 1942 Creutzfeldt put great effort into reversing a previous concatenation of a soldier who had deserted, which led to an avoidable death sentence [29]. Yet Creutzfeldt's son allegedly joined the resistance in 1942 and his wife was imprisoned in 1944 because she had made remarks critical of Hitler [29]. In 1954 Creutzfeldt informed the President of the Regional Court in Schleswig Holstein that the NS-euthanasia physician Werner Heyde (1902-1964) was employed as a medical reviewer at the court, but Creutzfeldt did not proceed any further when his letter failed to initiate an investigation of Heyde's case [30].

Andreas Rett (fig. 6), known for his struggle for the rights of mentally disabled children in the post-war era, was a member of the National Socialist German Workers' Party (NSDAP) [31] and had served in the German navy during the Second World War. In the early 1950s he started a clinic in Vienna for children with mental disorders despite opposition from influential colleagues who claimed, 'these idiots are a disgrace to the hospital' [32]. Many of his patients had survived the child 'euthanasia' 
project at Spiegelgrund [32]. Rett, who became a Freemason after the war, received a prestigious prize for his fight for the rights of disabled children. Zimperich et al. [32] call him a 'social reformer [offering] a dignified and purposeful life to many who had been considered a hopeless burden to society'. Yet Medline lists a paper from 1968 that Rett wrote together with Heinrich Gross, the NS-euthanasia physician referred to above [33]. Also, this paper was based on material from Spiegelgrund victims $[15,21$, 31]. Why would Rett cooperate with Gross who had ordered the killing of the very children whose rights Rett fought for so vigorously? One explanation might be that at that time in Austria there was little interest in uncovering the Nazi past [10]. Indeed, Gross was awarded the Ehrenkreuz für Wissenschaft und Kunst Erster Klasse (Cross for Accomplishments in Science and the Arts, First Class) by the Republic of Austria in 1975 (the prize was stripped only in 2003). It was not until 1981 that the Vienna High Court issued a verdict that Gross had indeed been involved in a considerable number of killings at Spiegelgrund hospital [34]. It is, therefore, likely that the readiness of the public to close its eyes to the atrocities committed during the Third Reich by fellow citizens extended into the medical profession. With this background one may begin to understand how Rett and Gross could cooperate. In the 1960s they happened to work at the same institution and despite all differences they shared a deep interest in pediatric neurology.

\section{Commentary}

How should eponyms associated with the Nazi era be dealt with? There are, somewhat simplified, 3 different approaches. First, some advocate abandoning these eponyms altogether, since they feel that criminals like
Hallervorden should no longer be honored [35]. Yet eponyms bring color into the world of medical science and they facilitate the reference to complex, often little understood diseases. Importantly, their rejection would not only wipe out the legacy of Nazis and other perpetrators, it would also delete the academic recognition of numerous victims and the few, yet so important, protesters. Second, some believe only eponyms derived from perpetrators should be abandoned, whereas those of victims should be emphasized [4]. While this approach may seem straightforward with many eponyms presented in this paper, there are numerous others that belong to a gray zone. As is obvious from the biographies of Creutzfeldt and Rett, the motives of the protagonists were as complex as the circumstances of the time. The third approach, therefore, states that eponyms should be kept and their historical origin emphasized, thereby raising the reader's awareness of the ethical context. The author favors this concept. Adding 'formerly' to the eponyms of those who clearly no longer should be honored (e.g. neurodegeneration with brain iron accumulation, formerly Hallervorden-Spatz syndrome) may be detrimental for readability, but it preserves the historical importance of the term. Most significantly, the scientists who lend their names to these eponyms would be remembered, not for their scientific achievements, but for their violation of medical ethics.

\section{Acknowledgments}

The author would like to thank Professor Wolfgang Neugebauer, Vienna, for invaluable information. Also the assistance of www.whonamedit.com in screening of medical eponyms relevant to this paper is hereby acknowledged. Further, the author is grateful for the help of www.commons.wikimedia.org which provided most of the graphic material.

\section{References}

1 Peiffer J: Die Vertreibung deutscher Neuropathologen 1933-1949. Nervenarzt 1998;69: 99-109.

-2 Shevell M: Neurosciences in the Third Reich: from ivory tower to death camps. Can J Neurol Sci 1999;26:132-138.

3 Hoche A, Binding R: Die Freigabe der Vernichtung lebensunwerten Lebens. Leipzig, Meiner, 1920

4 Strous RD, Edelman MC: Eponyms and the Nazi era: time to remember and time for change. Isr Med Assoc J 2007;9:207-224.
5 Hilberg R: Perpetrators, victims, bystanders: the Jewish catastrophe 1933-1945. New York, Harper Collins, 1993

-6 Shevell MI: Racial hygiene, active euthanasia, and Julius Hallervorden. Neurology 1992;42:2214-2219.

7 Spatz H: Zum 70. Geburtstag von Julius Hallervorden. Nervenarzt 1952;23:468.

8 Hallervorden J: Hugo Spatz zum 75. Geburtstag. Nervenarzt 1963;34:416-418.
9 Alexander L: Neuropathology and neurophysiology, including electro-encephalography in wartime Germany. Combined Intelligence Objectives Subcommittee 1945; item 24, file XXVII-1:1-65.

10 Neugebauer W, Stacher G: Nazi child 'euthanasia' in Vienna and the scientific exploitation of victims before and after 1945. Dig Dis 1999;17:279-285.

11 Dahlkamp J: Tiefstehende Idioten. Der Spiegel Oct 27, 2003, p 62. 
$\checkmark 12$ Seitelberger F: Die Merzbacher-Pelizaeus Krankheit. Klinisch-anatomische Untersuchungen zum Problem ihrer Stellung unter den diffusen Sklerosen. Wien Z Nervenheilkd Grenzgeb 1954;9:228-289.

13 Dahl M: Endstation Spiegelgrund: die Tötung behinderter Kinder während des $\mathrm{Na}$ tionalsozialismus am Beispiel einer Kinderfachabteilung in Wien 1940-1945. Wien, Erasmus, 1998.

14 Neugebauer W: Die Nachkriegskarriere des Euthanasiearztes Dr. Heinrich Gross. Informationen der Gesellschaft zur politischen Aufklärung 1999;60:3-4.

-15 Thomas FP, Beres A, Shevell M: A cold wind coming: Heinrich Gross and child euthanasia in Vienna. J Child Neurol 2006;21:342348.

16 Gross H, Rupprecht A, Seitelberger F: Anatomische Befunde bei Spättod nach Lachgasnarkose. Wien Z Nervenheilkd Grenzgeb 1955;10:397-405.

-17 Gross H, Kaltenbaeck E, Seitelberger F: Über eine systematisierte Fehlbildung des Rhombencephalons. Wien Klin Wochenschr 1962; 74:705-708.

$>18$ Gross H, Seitelberger F: Die pathologische Anatomie der zerebralen spastischen Paresen. Wien Med Wochenschr 1966;116:756760.

19 Seitelberger F, Gross H: Über eine spätinfantile Form der Hallervorden-Spatzschen Krankheit. II. Mitteilung: Histochemische Befunde. Erörterung der Nosologie. Dtsch Z Nervenheilkd 1957;176:104-125.

-20 Seitelberger F, Gootz E, Gross H: Beitrag zur spätinfantilen Hallervorden-Spatzschen Krankheit. Acta Neuropathol 1963;3:16-28.

21 Czech H: Dr Heinrich Gross: die wissenschaftliche Verwertung der NS-Euthanasie in Östereich; in Ganglmair S (ed): Dokumentationsarchiv des österreichischen Widerstandes, Jahrbuch 1999. Wien, Dokumentationsarchiv des österreichischen Widerstandes, 1999.

22 Seitelberger F, Gros H, Pilz P: Pick's disease: a neuropathologic study; in Hirano A, Miyoshi K (eds.): Neuropsychiatric Disorders in the Elderly. Tokyo, Aino Hospital Foundation Igaku-Shoin, 1983.

-23 Jellinger KA: In memoriam: Franz Seitelberger (1916-2007). Acta Neuropathol 2008; 115:157-158.
24 Simmer HH: Der Berliner Pathologe Ludwig Pick (1868-1944). Husum, Matthiesen, 2000.

25 Vogt O: Bericht über die Arbeiten des Moskauer Staatsinstituts für Hirnforschung. J Psychol Neurol 1929;40:108-118.

26 Klatzo I: Cecile and Oskar Vogt: the visionaries of modern neuroscience. Acta Neurochir 2002;80:S1-S130.

27 Katscher F: It's Jakob's disease, not Creutzfeldt's. Nature 1998;393:11.

28 Pearce JMS: Jacob-Creutzfeldt disease. Eur Neurol 2004;52:129-131.

29 Wolf JH, Foley P: Hans Gerhard Creutzfeldt (1885-1964): a life in neuropathology. J Neural Transm 2005;112:1-97.

30 Godau-Schüttke KD: Die Heyde/SawadeAffäre: wie Juristen und Mediziner in Schleswig-Holstein den NS-Euthanasiearz Werner Heyde deckten und straflos blieben, Teil 2. Schleswig-Holsteinische Anzeigen 1994:217-223.

31 Neugebauer W, Schwarz P: Der Wille zum aufrechten Gang. Wien, Czernin, 2005.

-32 Zimperich F, Ronen GM, Stögmann W, Baumgartner C, Stögmann E, Rett B, Pappas C, Leppert M, Singh N, Anderson VE: Andreas Rett and benign familial neonatal convulsions revisited. Neurology 2006;67:864866.

33 Gross H, Jellinger K, Kaltenbäck E, Rett A: Infantile cerebral disorders. Clinical neuropathological correlations to elucidate the aetiological factors. J Neurol Sci 1968;7:551564.

34 Berufungsentscheidung Oberlandesgericht Wien, 21 Bs 269/81, Mar 30, 1982.

35 Matteson E: All medical eponyms should be abandoned. Presse Méd 2008;2:250-251.

36 Pearce JMS: Neurodegeneration with brain iron accumulation: a cautionary tale. Eur Neurol 2006;56:66-68.

37 Peiffer J, Kleihes P: Hans-Joachim Scherer (1906-1945), pioneer in glioma research. Brain Pathol 1999;9:241-245.

38 Moltrech M, Michel O: The woman behind Frey's syndrome: the tragic life of Lucja Frey. Laryngoscope 2004;114:2205-2209.

39 Beighton P, Beighton G: The man behind the syndrome. Berlin, Springer, 1986.
40 Ferrarini A, Milani D, Bottigelli M, Cagnoli G, Selicorni A: Two new cases of BarraquerSimons syndrome. Am J Med Genet A 2004; 126:427-429.

41 Sterling W: Les phénomènes des doigts analogue aux signes de Babinski et de Rossolimo. Rev Neurol 1926;2:82.

42 Herman E: Neurolodzy Polscy. Warsaw, Panstwowy Zaklad, 1958.

43 Hallervorden J: In memoriam: zur Erinnerung an Max Bielschowsky 1869-1940. Nervenarzt 1959;30:325-327.

44 Gerstmann J, Sträussler E, Scheinker I: Über eine eigenartige hereditär-familiäre Erkrankung des Zentralnervensystems: zugleich ein Beitrag zur Frage des vorzeitigen lokalen Alterns. Zeitschr Ges Neurol Psych 1936;154:736-762.

45 Weirich A, Hoffmann GF: Ernst Moro (18741951): a great pediatric career started at the rise of university-based pediatric research but was curtailed in the shadows of Nazi laws. Eur J Pediatr 2005;164:599-606.

46 Bauer-Merinsky J: Die Auswirkungen der Annexion Österreichs durch das Deutsche Reich auf die medizinische Fakultät der Universität Wien im Jahre 1938: Biographien entlassener Professoren und Dozenten; dissertation, Wien, 1981.

47 Weber M: Psychiatric research and science policy in Germany: the history of the Deutsche Forschungsanstalt für Psychiatrie (German Institute for Psychiatric Research) in Munich from 1917 to 1945 . Hist Psychiatry 2000;11:235-258.

48 Firkin BG, Whitworth JA: Dictionary of medical eponyms, ed 2. London, Taylor \& Francis, 2001.

49 Clark D: Jules Tinel and Tinel's sign. Clin Plast Surg 1983;10:627-628.

50 Schirmer B: Autismus und NS-Rassengesetze in Österreich 1938: Hans Aspergers Verteidigung der "autistischen Psychopathen " gegen die NS-Eugenik. Neue Sonderschule 2002;6:450-454.

51 Ströhle A, Wrase J, Malach H, Gestrich C, Heinz A: Karl Bonhöffer (1868-1948). Am J Psychiatry 2008;165:575-576.

52 Nonne M: Anfang und Ziel meines Lebens: Erinnerungen. Hamburg, Christians, 1976.

53 Peiffer J: Zur Neurologie im 'Dritten Reich' und ihren Nachwirkungen. Nervenarzt 1998;69:728-733. 